\title{
REVIEW
}

\section{HOW SHOULD WARS BE FOUGHT? MILITARY STRATEGY VS POLITICAL DECISIONS}

An extremely interesting read can be had by any reader who buys Professor Donald Stoker's ${ }^{1}$ most recent book Why America Loses Wars - Limited War and US Strategy from the Korean War to the Present (Cambridge: Cambridge University Press, 2019), which analyzes the wars and conflicts fought by the United States of America since the Korean War. After the provocative title of the book, the reader begins to read with some suspicion, as it does not fit into the image of the United States as the world's leading power, one which can persuade almost all the countries of the world to deal with it either in political or economic or military cooperation. This is why it is shocking to face how differently the leaders of American and Western countries think about war; in many cases they do not even know exactly what it means, and what the consequences of its outbreak and the fighting can be. In several conflicts it can be seen that in the world's leading power, the political decision-makers thought in a completely different way in a given situation, often leading to conflicting decisions. This is not primarily due to political affiliation, but to the fact that the various actors involved in conflicts - politicians and soldiers - do not have a common vision of the goals and the results to be achieved or the strategies to be used. In many cases, it has

\footnotetext{
Donald Stoker was Professor of Strategy and Policy for the US Naval War College's Monterey Program at the Naval Postgraduate School in Monterey, California, from 1999 until 2017. The author or editor of 11 books, his Carl von Clausewitz: His Life and Work (Oxford University Press, 2014) is on the British Army professional reading list. The Grand Design: Strategy and the US Civil War, 1861-1865 (Oxford University Press, 2010) won the prestigious Fletcher Pratt award, was a Main Selection of the History Book Club, is on the US Army Chief of Staff's reading list, and is widely used as a text in strategic studies and history courses both in the US and abroad. In 2016, Stoker was a Fellow of the Changing Character of War Programme at the University of Oxford's Pembroke College. During the 2017-2018 academic year he was the Fulbright Distinguished Professor of Political Science at the Diplomatic Academy in Vienna, Austria. He is currently a Senior Fellow with the Atlas Organization in Washington, DC, and is writing American Grand Strategy, 1775-2020 for Basic Books. His most recent book is Why America Loses Wars: Limited War and US Strategy From the Korean War to the Present (Cambridge University Press, 2019). He lives in Monterey, California.
} 
led to unnecessary losses and wars that have gone on far longer than they needed to - see Iraq and Afghanistan.

Policymakers are often unaware of the old wisdom of Carl von Clausewitz - often quoted by Stoker - formulated in his book On War, "War as Politics by other Means". This assumes that politicians start a conflict with clear objectives, knowing exactly what results they want to achieve. In addition, they are aware that the success of a war, however short-term or limited, may be influenced by factors such as the geographical environment, economic background, logistical capabilities, social support, historical and cultural background, and so on. However, some of these factors may change during the conflict, so the objectives and strategies need to be reviewed from time to time and, if necessary, redesigned according to the realities of the time.

Jordan Ellenberg took a similar view of these old truths in his book, How Not to Be Wrong: The Power of Mathematical Thinking; he said "Countries don't win wars just being braver than the other side, or freer, or slightly preferred by God. The winners are usually the guys who get $5 \%$ fewer of their planes shot down, or use $5 \%$ less fuel, or get $5 \%$ more nutrition into their infantry at $95 \%$ of the cost. That's not the stuff war movies are made of, but it's the stuff wars are made of. And there's math every step of the way"2. Even so, these things are constantly forgotten by most political decisionmakers who lead their countries into endless wars, the consequences of which are suffered by the soldiers fighting the battles and the civilian population in the areas affected. Therefore, Stoker can rightly hold these decision-makers accountable for their lack of the proper application of strategic thinking. This is particularly important in view of the fact that the period of "limited war" which has characterized the last two decades is coming to an end, and the US may face increasingly equal opponents like China or Russia. The conflict against them is expected to be conventional, for which the American political and military leadership, accustomed to anti-insurgency operations and rapid success, is unlikely to be properly prepared. From this point of view, the book could even act as an alarm bell, so that leaders can begin preparations for the later period, although the author did not suggest how what he had articulated could be put into practice.

One of the major strengths of the book is that it clarifies commonly used political and military concepts such as unilateralism, multilateralism, types of political objective, strategy, tactics, objectives, operations, pre-emptive and preventive war, gray zone war, limited war, little war, nested war, victory and peace. The other serious strength of the book is that it almost fanatically emphasizes the need for more active, effective dialogue and cooperation between the political and military sides, as a result of which interpretation problems between different groups and actors can be significantly reduced and cooperation can be improved. It was particularly interesting to me that the author presented several political and military events - not only from American but also from international environments - and the decision-making processes leading

2 Jordan Ellenberg: How Not to Be Wrong: The Power of Mathematical Thinking, Penguin, 2014, p 7 
to them and their background, which many historians and military historians are not fully aware of. In addition to describing historical events, the author lists a large number of military and political strategists, such as Sun Tzu, Carl von Clausewitz, or Bernard Brodie (better known in the United States), and others, and he also outlines their thoughts - even if he disagrees with some of them - which in some way still have an impact on warfare to this day. However, in addition to the many positives, I missed the fact that although the author presented almost every American conflict in recent decades, he only talked about the US "getting into endless wars", and not how on several occasions the war - as in Grenada, Panama, or the Balkans - also achieved its goal. Here, perhaps, it would have been worthwhile to take a closer look at what these successes were due to and to draw conclusions from them. However, this does not detract from the value of the book.

I especially liked that Stoker stayed true to his university teaching past and built his book in a way that even those who are less familiar with the subject could profit from. This is aided by clear explanations and extensive discussions of the various concepts. This helps readers from different backgrounds get a unified picture of how political decision-making takes place, what a war is, how to fight it and, most importantly, how to finish it, what the different actors think about it, and the differences in the way of thinking of politicians and soldiers involved in war. On the other hand, it could also be extremely useful to political and strategic decision-makers, who often make decisions that have a very serious impact with minimal knowledge and a lack of adequate background information. As a veteran of 31 years as a professional soldier, one who began his career as a sergeant in the troops and finished as a colonel on the General Staff, I fully agree with the author's book, which should be read not only by American but all other countries' political and military leaders, as a kind of basic strategic course material to know how to make informed decisions on military issues, how to communicate successfully and intelligibly between political decision-making and the military communities implementing them, and what the consequences of the decisions they make may be. 